\title{
KEBERSYUKURAN DAN KEBERMAKNAAN HIDUP PADA PENDERITA JANTUNG KORONER
}

\author{
GRATITUDE AND MEANINGFULNESS OF LIFE \\ ON CORONARY HEART PATIENTS
}

\author{
Oleh : \\ Izanatul Laily Maulidah *)
}

\begin{abstract}
ABSTRAK
Penelitian ini bertujuan untuk mengetahui hubungan kebersyukuran dan kebermaknaan hidup pada penderita jantung koroner di Poliklinik Penyakit Dalam RSUD Hj. Anna Lasmanah Banjarnegara. Jumlah partisipan dalam penelitian ini yaitu 65 pasien.Alat pengumpulan data menggunakan skala kebersyukuran dan skala kebermaknaan hidup. Dari uji validitas, diperoleh koefisien validitas skala kebersyukuran bergerak dari 0,252 sampai 0,508 dengan $r_{\text {tabel }}=0,244$, sementara validitas skala kebermaknaan hidup bergerak dari 0,322 sampai 0,496 dengan $r_{\text {tabel }}=0,244$. Hasil uji reliabilitas skala kebersyukuran diperoleh nilai sebesar 0,879 dan skala kebermaknaan hidup sebesar 0,890.Analisis data dalam penelitian ini menggunakan teknik analisis regresi linier sederhana. Hasil uji hipotesis menunjukkan $r_{\text {hitung }}$ sebesar 0,726 dan $r_{\text {tabel }}$ $0,244 p$ sebesar 0,000 dengan taraf kepercayaan 99\% $(\alpha=0,01)$, hal ini menunjukkan bahwa $r_{\text {hitung }}>r_{\text {tabel }}(0,726>0,244)$ maka arah hubungan adalah positif. Dimana semakin tinggi kebersyukuran maka semakin tinggi kebermaknaan hidupnya, begitu juga sebaliknya jika semakin rendah kebersyukuran maka akan semakin rendah pula kebermaknaan hidupnya. Sumbangan efektif variabel kebersyukuran adalah sebesar 52,7\% terhadap kebermaknaan hidup, sementara 47,3\% merupakan sumbangan efektif dari faktor lain yang tidak diteliti.
\end{abstract}

Kata Kunci : Kebersyukuran, Kebermaknaan Hidup, Penderita Jantung Koroner

\section{ABSTRACT}

This study aims to determine the relationship gratitude and meaningfulness of life in patients with coronary heart disease in the Polyclinic of Internal Medicine RSUD Hj. Anna Lasmanah Banjarnegara. The number of participants in this study were 65 patients. Data collection tools use scale of gratitude and scale of meaningfulness of life. From the validity test, the validity scale validity coefficient is obtained from 0.252 to 0.508 with rtabel $=0.244$, while the validity of the life meaning scale moves from 0.322 to 0.496 with rtabel $=0.244$. Reliability test results of scale of gratitude obtained value of 0.879 and life-meaning scale of 0.890. Data analysis in this research using simple linear regression analysis technique.

*) Alumni Fakultas Psikologi - Universitas Muhammadiyah Purwokerto 
The result of hypothesis test shows that rcount is 0,726 and rtabel 0,244 $p$ is 0.000 with level of trust of $99 \%(\alpha=0,01)$, it shows that rhitung $>$ rtabel $(0,726>0,244)$ hence direction of relation is positive. Where the higher gratitude the higher meaningfulness of his life, and vice versa if the lower gratitude it will lower the meaningfulness of his life. The effective contribution of the gratitude variable is $52.7 \%$ of the meaningfulness of life, while $47.3 \%$ is an effective contribution from other factors not examined.

Keywords: level of gratitude, life meaningfulness, coronary heart disease

\section{PENDAHULUAN}

Perubahan pola hidup menimbulkan dampak yang cukup besar dalam masyarakat. Dengan adanya perubahan pola hidup yang terjadi terutama pada orang muda yang tinggal di perkotaan, pada saat ini ada kecenderungan penyakit jantung koroner dapat diderita oleh pasien dibawah usia 40 tahun. Hal ini tentu menimbulkan peningkatan jumlah penderita jantung di Indonesia (Wijayakusuma, 2005).

Siantoro (2014) mengungkapkan bahwa penyakit jantung koroner terjadi karena adanya penyempitan pembuluh darah akibat atheroma atau tumpukan kolesterol.Penumpukan tersebut dimulai dari masa kanak-kanak dan terus terakumulasi. Kecepatan proses penumpukan tersebut dapat berbeda pada setiap orang, tergantung dari perilaku dan gaya hidup. Faktor lain yang dapat menentukan kecepatan penumpukan atheroma adalah cardiovascular reactivityi (CVR) atau seberapa sering, besar dan lamanya kenaikan tekanan darah dan denyut jantung seseorang. Denyut jantung dan tekanan darah yang sering meningkat secara drastis dan sulit turun menyebabkan jaringan pembuluh darah cepat rusak. Jaringan yang rusak tersebut akan menumpuk dan kemudian menyumbat pembuluh darah sehingga dapat memicu serta memperparah penyakit jantung koroner.

Pratiwi (2009) mengungkapkan gejala psikologis yang dialami penderita jantung koroner ditunjukkan semenjak pertama kali individu divonis mengalami penyakit jantung koroner diantaranya subjekakan merasa terkejut (shock), selanjutnya akan timbul rasa kecemasan (anxiety) karena ancaman kekambuhan atau bahkan kematian yang dapat terjadi sewaktu-waktu. Individu juga akan merasa tidak berdaya karena tidak dapat melakukan apapun dan merasa sesuatu yang buruk akan menimpa, serta merasa kegiatannya dibatasi dari akibat penyakit jantung. Pada individu yang lain akan merasa bosan, kesepian, bahkan merasa diasingkan oleh lingkungan.

Kondisi mental negatif seperti kecemasan, perasaan tidak berdaya, hilangnya minat, kurangnya inisiatif, mempunyai perasaan hampa, merasa tidak memiliki tujuan hidup, merasa tidak berarti, serba bosan dan selalu memikirkan tentang kematian menjadikan kebermaknaan hidup menjadi masalah berikutnya 
yang muncul. Kondisi tersebut merupakan bentuk dari hilang atau berkurangnya kebermaknaan hidup pada seseorang (Frankl dalam Koeswara, 1992).

Menurut Bastaman (2007) kebermaknaan hidup adalah hal-hal yang dianggap sangat penting dan berharga serta memberikan nilai khusus bagi seseorang, sehingga layak dijadikan tujuan dalam kehidupan (the purpose in life). Bila hal itu berhasil dipenuhi akan menyebabkan seseorang merasakan kehidupan yang berarti dan pada akhirnya akan menimbulkan perasaan bahagia (happiness). Menurut Emmons dkk, (2007), dalam beberapa penelitian yang telah dilakukan tidak hanya menunjukkan keadaan mental yang lebih positif (misalnya antusias, tekun, dan penuh perhatian), tetapi juga lebih murah hati, peduli, dan membantu orang lain. Sehingga kebersyukuran dapat dilihat sebagai salah satu upaya dalam meningkatkan makna di dalam kehidupan.

Lyubomirskry (2007) mengungkapkan ketika seseorang mampu menerimadan bersikap tabah pada saat menghadapi penyakit kronis seperti jantung koroner, dapat membantu untuk menyesuaikan diri dan melanjutkan kehidupan, serta membuat hidup menjadi lebih bahagia.Hal tersebut dapat menunjang rasa penghargaan diri (self esteem) dan kebergunaan diri (self worth).Praktek bersyukur juga bertentangan dengan emosi negatif dan bahkan mengurangi atau menghalangi munculnya perasaan marah akibat penyakit yang dideritanya.Frankl (dalam Bastaman, 2007) mengungkapkan bahwa sikap menerima dengan penuh ikhlas dan tabah dari hal-hal tragis yang tidak mungkin dielakkan lagi merupakan sumber dari hidup yang bermakna.

Seligman (2004) mendefinisikan syukur sebagai a sense of thankfulness and joy in response to receiving a gift, whether the gift be a tangible benefit from a specific other or a moment of peaceful bliss evoked by natural. Dengan kata lain bersyukur adalah suatu perasaan terimakasih dan menyenangkan atas respon penerimaan hadiah, yang mana hadiah itu memberikan manfaat dari seseorang atau suatu kejadian yang memberikan kedamaian.

Aspek-aspek yang digunakan dalam penelitian ini merujuk pada dikemukakan oleh Wood (2008), yaitu penghargaan orang lain, kepemilikan, momen pemberian, ritual, perasaan akan kekaguman, pembandingan diri/sosial, kekhawatiran eksistensial, dan perilaku kebersyukuran.

Berdasarkan uraian tersebut, maka tujuan dari penelitian ini adalah untuk mengetahui hubungan antara kebersyukuran dan kebermaknaan hidup pada pasien jantung koroner di Poliklinik Dalam RSUD Hj. Anna Lasmanah Banjarnegara.

\section{METODE PENELITIAN}

\section{Variabel Penelitian}

Variabel terikat dalam penelitian ini adalah kebermaknaan hidup, sedangkan variabel bebas adalah kebersyukuran. 


\section{Subjek Penelitian}

Subjek dalam penelitian ini adalah pasien jantung koroner di Poliklinik Dalam RSUD HJ. Anna Lasmanah Banjarnegara, dengan diambil sampel 65 pasien jantung koroner.

\section{Metode dan Instrumen Pengumpulan Data}

Metode pengumpulan data dalam penelitian ini menggunakan instrumen skala kebersyukuran dan skala kebermaknaan hidup.Dari uji validitas, diperoleh koefisien validitas skala kebersyukuran bergerak dari 0,252 sampai 0,508 dengan rtabel $=0,244$, sementara validitas skala kebermaknaan hidup bergerak dari 0,322 sampai 0,496 dengan rtabel $=0,244$. Hasil uji reliabilitas skala kebersyukuran diperoleh nilai sebesar 0,879 dan skala kebermaknaan hidup sebesar 0,890.

\section{Metode Analisis Data}

Analisis data dalam penelitian ini menggunakan teknik analisis regresi linier sederhana.

\section{HASIL PENELITIAN DAN PEMBAHASAN}

Berdasarkan hasil analisis data yang telah dilakukan, diketahui bahwa ada hubungan yang signifikan antara kebersyukuran dengan kebermaknaan hidup. Hasil uji hipotesis $r_{\text {hitung }}$ sebesar 0,726 dan $r_{\text {tabel }}$ 0,244 p sebesar 0,000 dengan taraf kepercayaan $99 \%(\alpha=0,01)$, hal ini menunjukkan bahwa $r_{\text {hitung }}>r_{\text {tabel }}$ $(0,726>0,244)$ maka arah hubungan adalah positif. Dalam penelitian ini kebersyukuran memiliki sumbangan efektif sebesar $52,7 \%$ terhadap kebermaknaan hidup, berarti masih ada $47,3 \%$ faktor lain yang berkaitan.

Hasil analisis menunjukkan bahwa semakin tinggi kebersyukuran maka semakin tinggi kebermaknaan hidupnya, begitu juga sebaliknya jika semakin rendah kebersyukuran maka akan semakin rendah pula kebermaknaan hidupnya. Pasien jantung koroner diharapkan memiliki kebersyukuran yang baik, karena pasien akan memiliki kebermaknaan hidup yang baik pula. Namun disisi lain terdapat $47,3 \%$ faktor lain yang berpengaruh terhadap kebermaknaan hidup pasien jantung koroner, antara lain frustasi ekstensi dan neurosis noogenik (Frankl, 2003).

Penderita jantung koroner dengan disposisi bersyukur yang kuat ketika mengalami kejadian positif akan merasakan kebersyukuran yang lebih sering dibandingkan penderita yang memiliki disposisi kebersyukuran yang lebih rendah. Penderita juga lebih sering mengucap syukur setiap harinya, cenderung menerima mensyukuri segala hal yang dimiliki, serta senang membangun hubungan positif dengan orang lain (Peterson, 2004).

Kebersyukuran diketahui membantu seseorang untuk dapat menyesuaikan diri, melanjutkan kehidupan, atau memulai kehidupan baru bagi individu yang mengalami kesulitan pribadi seperti kehilangan atau menghadapi penyakit kronis seperti jantung koroner (Lyubomirskry, 2007). Dengan memiliki rasa syukur atas 
penyakit yang dialami, penderita jantung koroner akan mampu menyesuaikan diri terhadap perubahan kondisi fisiknya, hal tersebut akan membantu dalam menjalani kehidupan yang lebih baik sebagai penderita jantung koroner.

Kebersyukuran yang rendah ditunjukkan penderita dengan cenderung tertutup dan tidak membangun hubungan baik dengan orang lain, sering merasakan kekecewaan karena merasa gagal, serta cenderung muncul emosi negatif seperti perasaan amarah dalam diri. Penderita dengan kebersyukuran yang rendah akan memunculkan perasaan iri terhadap apa yang dimiliki orang lain, serta cenderung sulit menghadapi efek dari adaptasi hedonisme (Lyubomirskry, 2007).

Berdasarkan hasil penelitian yang telah dilakukan menunjukkan bahwa mayoritas penderita memiliki kebersyukuran sedang sehingga mayoritas penderita juga memiliki kebermaknaan hidup yang sedang pula.Namun terdapat pula penderita dengan kebersyukuran yang tinggi dan rendah, serta beberapa penderita memiliki kebersyukuran yang rendah.Begitu pula dengan hasil penelitian kebermaknaan hidup yang dimiliki oleh penderita.

Dari hasil penelitian, diketahui penderita jantung koroner yang memiliki kebersyukuran tinggi menunjukkan keadaan mental yang lebih positif terhadap kondisi dirinya, seperti: dapat menerima keadaan dirinya, lebih murah hati, lebih menjaga emosi, mampu merubah pola hidup menjadi lebih sehat, serta rutin menjalani pengobatan. Pada umumnya penderita tidak membutuhkan waktu yang lama untuk menerima perubahan kondisi fisiknya.Penderita jantung koroner yang memiliki kebersyukuran sedang menunjukkan sikap yang cukup baik.Penderita pada awalnya mengalami kekecewaan terhadap keadaan dirinya, namun lambat laun penderita mulai menerima keadaan dirinya. Penderita jantung koroner yang memiliki rasa syukur yang rendah menunjukkan sikap yang negatif seperti: merasa tidak berharga dan tidak berdaya, merasa putus asa, menarik diri dari pergaulan, serta tidak dapat menerima perubahan kondisi yang dialami.

Individu yang bersyukur mempunyai nilai-nilai yang mereka tunjukkan dengan mengakui bahwa semua hal yang didapat hanya dari Tuhan bukan dari siapa-siapa.Nilai inilah yang dimiliki individu yang bersyukur sebagai suatu kerangka yang harus dipenuhi agar membuat hidup jauh lebih bermakna. Individu yang bersyukur di indikasikan tidak akan merasa tersesat dalam hidup dan dinyatakan mempunyai perasaan meluap-luap. Ini berarti sudah memenuhi konsep hidup bermakna yaitu hidup bersemangat, penuh gairah dan tidak mudah bosan serta tidak merasa hampa.Individu yang bersyukur juga mempunyai kecendrungan untuk menghargai kebahagiaan kecil sekalipun sehingga jika mengalami penderitaan atau musibah, tetap bersikap tabah serta sadar bahwa selalu ada hikmah dibalik musibah itu yang juga merupakan salah satu indikator hidup yang bermakna.

Berdasarkan uraian diatas menunjukkan adanya hubungan yang positif antara kebersyukuran dan kebermaknaan hidup pada penderita jantung koronerdi 
RSUD Hj. Anna Lasmanah Banjarnegara.Bastaman (2005) mengungkapkan bahwa kebermaknaan hidup adalah sangat penting karena memberikan nilai khusus bagi seseorang sehingga layak dijadikan tujuan dalam kehidupan (the purpose in life).Oleh kerena itu perlu adanya sikap kebersyukuran dalam diri penderita jantung koroner agar penderita mampu merumuskan dan mencapai tujuan yang diinginkan dalam hidupnya.

Namun penelitian lanjutan diperlukan untuk mengetahui faktor lain yang berkaitan dengan kebermaknaan hidup pada penderita jantung koroner di RSUD $\mathrm{Hj}$. Anna Lasmanah Banjarnegara. Dimana faktor lain yang dapat diungkap adalah frustasi ekstensi dan neurosis noogenik, yang diakibatkan oleh dimensi keberadaan manusia yaitu secara khusus terkait dengan dimensi humanis atau manusiawi seorang manusia yang muncul karena masalah-masalah hidup.

\section{KESIMPULAN}

Hasil uji hipotesis menunjukkan $r_{\text {hitung }}$ sebesar 0,726 dan $r_{\text {tabel }} 0,244 \mathrm{p}$ sebesar 0,000 dengan taraf kepercayaan 99\% $(\alpha=0,01)$, hal ini menunjukkan bahwa $r_{\text {hitung }}>r_{\text {tabel }}(0,726>0,244)$ maka arah hubungan adalah positif. Dimana semakin tinggi kebersyukuran maka semakin tinggi kebermaknaan hidupnya, begitu juga sebaliknya jika semakin rendah kebersyukuran maka akan semakin rendah pula kebermaknaan hidupnya.Sumbangan efektif variabel kebersyukuran adalah sebesar 52,7\% terhadap kebermaknaan hidup, sementara 47,3\% merupakan sumbangan efektif dari faktor lain yang tidak diteliti.

\section{DAFTAR PUSTAKA}

Bastaman, H.D. (2007). Logoterapi Psikologi untuk Menemukan Makna Hidup dan Meraih hidup Bermakna. Jakarta: Raja Grafindo Persada.

Emmons,R., \&Cullough, M. (2003).Counting Blessings Versus Burdens: An Experimental Investigation of Gratitude and Subjective Well-Being in Daily Life. Jounal of Personality and Social Psychology, 2, (84), 377-389.

Frankl, V. E. (2003). Logoterapi Terapi Psikologi Melalui Pemaknaan Eksistens. (Terjemahan M. Murtadlo). Yogyakarta: Kreasi Wacana.

Koeswara, E. (1992). Logoterapi Psikoterapi Viktor Frankl. Yogyakarta: Kanisius.

Lyubomirsky, Sonja. Et all. (2007). Is It Possible to Become Happier? (And If So, How?). Social and Personality psychology Compass: 129-145, 10.111/j.1751-9004.2007.00002.x. Blackwell Publishing, Ltd.

Peterson, C.,\& Seligman, M. E. P. (2004).Character, Strenght, and Virtues: A Handbook \& Classification. New York: Oxford University press. 
Pratiwi, H. (2009). Social Support pada Lansia Penderita Penyakit Jantung Koroner.Skripsi.Fakultas Psikologi Universitas Sumatra Utara.

Seligman, M. E. P. (2005). Menciptakan Kebehagiaan dengan Psikologi Pasif Authentic Happiness.Bandung: PT. Mizan Pustaka.

Siantoro, A. P. (2014). Faktor Psikologis dari Penyakit jantung Koroner.online. http://Ruangpsikologi.com/kesehatan/faktor-psikologis-dari-penyakitjantung-koroner/(diakses tanggal 20 November 2014)

Wijayakusuma, H.(2005). Menghindari penyakit jantung dan stroke dengan pola hidup sehat.Portal CBN - $\quad$ Cyberhealth: http://portal.cbn.net.id/cbprtl/cybermed/detail.aspx?x=Hembing\&y=cybermed\%7C0\%7C 0\%7C8\%7C77. (diakses tanggal 20 November 2014)

Wood, A. M. (2008). Individual Differences in Gratitude and Their Relationship with Well Being. University of Warwick. 